\title{
PERUBAHAN PENGGUNAAN LAHAN DAN KELESTARIAN PRODUKSI PLTA WAY BESAI DI PROVINSI LAMPUNG
}

\author{
(Land Use Change and Sustainable Production of Way Besai \\ Hydropower in Lampung Province)
Bambang Soeharto ${ }^{1}$, Cecep Kusmana ${ }^{2}$, Dudung Darusman², Didik Suharjito ${ }^{3}$
${ }^{1}$ Sekolah Pascasarjana, Program Studi Pengelolaan SDA dan Lingkungan IPB, Bogor e-mail: nagrem_bs@hotmail.com
${ }^{2}$ Fakultas Kehutanan Institut Pertanian Bogor
${ }^{3}$ Fakultas Kehutanan Institut Pertanian Bogor
Kampus Dramaga Bogor

Naskah masuk : 21 Maret 2011; Naskah diterima : 8 Februari 2012

\begin{abstract}
Forest conversion to other land use systems will affect to water supply, both in quantity and quality due to environment services function. Based on the land use change scenario had also been quantified to know land use composition in Sumberjaya which provide the maximum hydropower income. Total hydropower income in Sumberjaya Sub-district, West Lampung District, Lampung Province is affected by land use system composition. Simulation based on land use change scenarios (scenario 1: 13\% monoculture coffee; scenario 2: 61\% agroforestry base on coffee; scenario 3: 23\% forest; scenario 4: $30 \%$ forest and scenario 5: 84\% forest) were done to predict total hydropower income in different type composition. Sustainable total hydropower income occurres when $61 \%$ of total area covered by coffee based agroforestry, but the lowest income occurres when $84 \%$ of area covered by forest. In opposite, reforestation in Sumberjaya sub-district areas, except paddy field, horticulture land and settlement will decrease $13.5 \%$ of total income.
\end{abstract}

Keywords: Agroforestry, coffee, hydropower income, scenario

\begin{abstract}
ABSTRAK
Alih guna lahan hutan menjadi sistem penggunaan lainnya akan menimbulkan masalah terhadap suplai air sebagai fungsi penyedia jasa lingkungan secara kuantitas maupun kualitas Skenario perubahan penggunaan lahan juga dikuantifikasikan untuk mengetahui komposisi penggunaan lahan di Sumberjaya yang memberikan pendapatan maksimum bagi Pembangkit Listrik Tenaga Air (PLTA). Total PLTA di Kecamatan Sumberjaya, Kabupaten Lampung Barat, Provinsi Lampung dipengaruhi oleh komposisi penggunaan lahan. Simulasi didasarkan pada skenario perubahan penggunaan lahan (skenario 1: 13\% monokultur; skenario 2: 61\% agroforestri berbasis kopi; skenario 3: 23\% hutan; skenario 4: $30 \%$ hutan dan skenario 5: 84\% hutan) untuk memprediksi total pendapatan PLTA yang berkelanjutan. Hasil penelitian menunjukkan bahwa total pendapatan PLTA yang memberikan keberlanjutan terjadi ketika $61 \%$ total area ditutupi oleh agroforestry berbasis kopi dan total pendapatan terendah terjadi ketika total areal ditutupi 84\% hutan. Sebaliknya penghutanan seluruh areal di Kecamatan Sumberjaya kecuali lahan padi, hortikultur dan perumahan akan menurunkan total pendapatan PLTA sebesar 13,5\%.
\end{abstract}

Kata kunci : Agroforestry, kopi, pendapatan PLTA, skenario 


\section{PENDAHULUAN}

Pertambahan penduduk di Kecamatan Sumberjaya, baik yang terjadi karena pertumbuhan maupun migrasi dari daerah lain menuntut tersedianya lahan garapan untuk usaha tani dan pemukiman. Alih guna lahan hutan menjadi sistem pertanian intensif merupakan salah satu alternatif untuk meningkatkan pendapatan petani, sehingga telah terjadi pembukaan lahanlahan secara besar-besaran di daerah tersebut (terutama membaiknya harga kopi dunia periode 1970 an dan 1980 an) seperti kopi monokultur, kopi naungan sederhana maupun agroforestry berbasis kopi (Budidarsono dan Wijaya, 2004).

Lajunya tingkat penurunan tutupan hutan hingga 50\% antara tahun 1970-an hingga 2000-an (Verbist et al., 2005) telah menurunkan tingkat kualitas lingkungan hidup, kondisi tersebut terjadi karena adanya ketidak harmonisan antara aktifitas ekonomi dengan keterbatasan kapasitas sumberdaya alam yang tersedia yang dapat dimanfaatkan untuk memenuhi kebutuhan manusia. Artinya semakin besar potensi dan eksploitasi sumberdaya alam tersebut, dampaknya terhadap degradasi kualitas lingkungan juga cenderung meningkat menurut dimensi ruang (lokal, regional dan global) dan waktu (jangka panjang) terhadap lingkungan (Tietenberg, 1992).

Alih guna lahan hutan menjadi penggunaan lain telah disadari banyak pihak akan menimbulkan beberapa masalah lingkungan, antara lain hilangnya fungsi jasa lingkungan dari hutan terutama sebagai pengatur tata air, pengatur iklim, pengatur keseimbangan hama/ penyakit dan pengatur dalam proses regenerasi tanaman (Millenium Ecosystem Assessment, 2005). Namun demikian, sampai saat ini keberadaan hutan dianggap kurang memberikan manfaat langsung bagi masyarakat yang membutuhkan lahan garapan. Konflik kepentingan antara kelestarian sumberdaya alam (kelestarian ekologis) dengan kebutuhan ekonomi telah terjadi di Kecamatan Sumberjaya, Lampung. Oleh karena itu mencari jalan tengah melalui penataan kawasan hutan untuk menghasilkan komposisi tutupan lahan yang optimal sebagai penyedia jasa lingkungan (sumberdaya air) sekaligus menjaga kelestarian produksi pembangkit listrik tenaga air (PLTA) Way Besai perlu dilakukan untuk mencapai keberlanjutan sosial, ekonomi dan ekologi dari ekosistem hutan di daerah tersebut. Penelitian ini dilakukan dengan tujuan untuk mengkaji komposisi sistem penggunaan lahan yang mampu menjamin kelestarian produksi PLTA dengan pendapatan yang maksimal.

\section{METODE PENELITIAN}

\section{A. Lokasi Penelitian}

Penelitian dilakukan di Kecamatan Sumberjaya yang mencakup areal seluas 54.200 hektar dan berada di sub daerah aliran sungai (Sub-DAS) Way Besai, Kabupaten Lampung Barat, Provinsi Lampung. Secara geografis lokasi penelitian berada antara $04^{\circ} 98^{\prime} \mathrm{LS}-05^{\circ} 07^{\prime}$ LS dan $104^{\circ} 23^{\prime}$ BT - 104 $34^{\prime}$ BT (Gambar 1).

\section{B. Metode Penelitian}

\section{Pengumpulan data}

Data yang dikumpulkan dalam penelitian ini antara lain: (1) luasan tutupan lahan yang diklasifikasikan sebagai hutan, agroforestry berbasis kopi (kopi ditanam bersama pohon kayu dan buah-buahan), kopi naungan sederhana (kopi ditanam dengan tanaman penaung seperti gamal dan dadap), kopi monokultur, horikultura, sawah, belukar dan pemukiman; (2) curah hujan; (3) intensitas hujan; (4) infiltrasi air; (5) aliran permukaan; (6) harga jual listrik per Kwh dari PLTA ke masyarakat pemakai listrik dan (7) kapasitas turbin pembangkit listrik.

\section{Penentuan Penentuan Skenario Peruba- han Penggunaan Lahan}

Penentuan skenario perubahan penggunaan lahan didasarkan atas kondisi aktual yang terjadi di Kecamatan Sumberjaya saat ini, seperti terlihat pada Gambar 2, Skenario yang dikembangkan mampu memberikan pendapatan optimal bagi PLTA(Tabel 1).

Adapun kelima skenario tersebut adalah:

\section{a. Skenario 1}

Skenario ini dilakukan untuk mengetahui kontribusi lahan semak belukar terhadap total pendapatan masyarakat jika dilakukan penanaman kopi monokultur. Luas lahan kopi monokultur 9\% dan semak belukar 4\% dari total luas lahan pada kondisi aktual yang diubah menjadi kopi monokultur, adapun luas lahan hutan, kopi naungan sederhana dan agroforestry berbasis kopi tetap sehingga luas lahan kopi monokultur pada skenario 1 menjadi $13 \%$. 


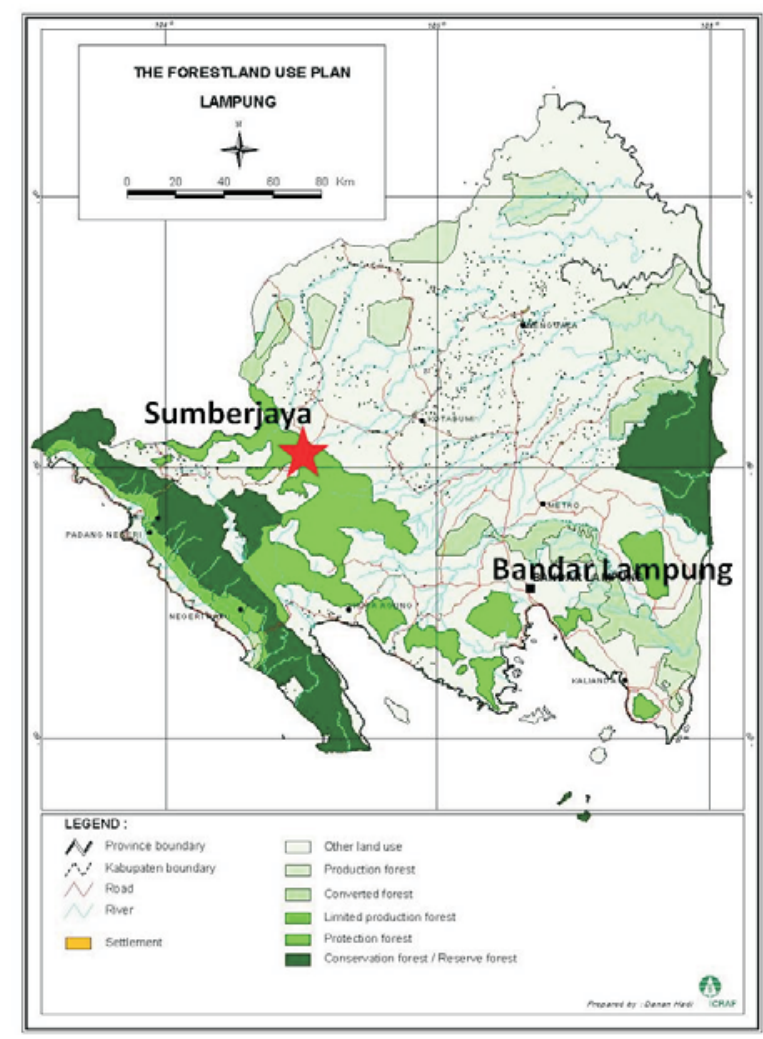

Gambar (Figure) 1. Peta lokasi penelitian (Map of research location)

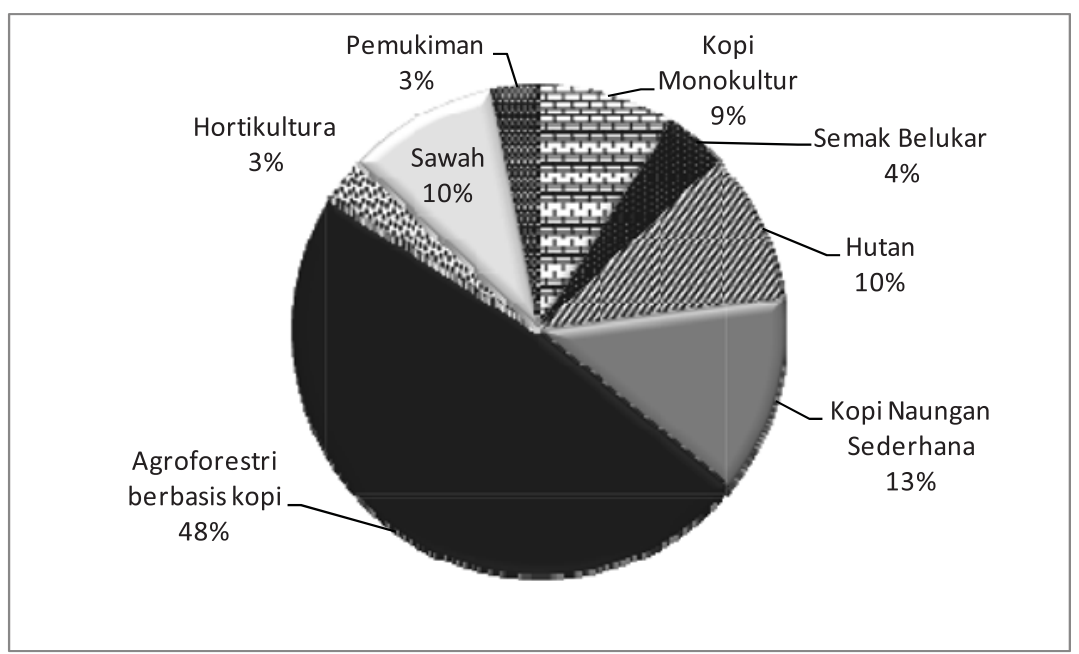

Gambar(Figure) 2. Penggunaan lahan aktual di Kecamatan Sumberjaya (Actual landuse in Sumberjaya sub-district)

\section{b. Skenario 2}

Skenario dilakukan dengan mengubah lahan kopi monokultur dan semak belukar menjadi lahan agroforestri berbasis kopi adalah untuk mengetahui kontribusi agroforestri berbasis kopi terhadap pendapatan total masyarakat. Lahan tanaman kopi monokultur 9\% dan semak belukar 4\% dari total luas lahan pada kondisi aktual diubah menjadi agroforestry berbasis kopi, luas lahan hutan dan kopi naungan sederhana tetap tidak berubah sehingga luas lahan agroforestri berbasis kopi pada skenario 2 menjadi $61 \%$. 
Tabel (Table) 1. Kondisi aktual dan skenario penggunaan lahan di lokasi penelitian (Actual condition and landuse scenario in research location)

\begin{tabular}{|c|c|c|c|c|c|c|}
\hline \multirow{2}{*}{ Tipe tutupan lahan } & \multirow{2}{*}{$\begin{array}{c}\text { Aktual } \\
(\%)\end{array}$} & \multicolumn{5}{|c|}{ S k e n a ri o (\% luas penggunaan lahan) } \\
\hline & & 1 & 2 & 3 & 4 & 5 \\
\hline Kopi Monokultur & 9 & 13 & 0 & 0 & 0 & 0 \\
\hline Semak Belukar & 4 & 0 & 0 & 0 & 0 & 0 \\
\hline Hutan & 10 & 10 & 10 & 23 & 30 & 84 \\
\hline Kopi Naungan Sederhana & 13 & 13 & 13 & 13 & 13 & 0 \\
\hline Agroforestri berbasis kopi & 48 & 48 & 61 & 48 & 41 & 0 \\
\hline Hortikultura & 3 & 3 & 3 & 3 & 3 & 3 \\
\hline Sawah & 10 & 10 & 10 & 10 & 10 & 10 \\
\hline Pemukiman & 3 & 3 & 3 & 3 & 3 & 3 \\
\hline Total $(\%)$ & 100 & 100 & 100 & 100 & 100 & 100 \\
\hline
\end{tabular}

\section{c. Skenario 3}

Skenario ini dilakukan untuk mengetahui kontribusi agroforestry berbasis kopi terhadap total pendapatan masyarakat dengan meningkatnya luas penggunaan hutan. Luas lahan kopi monokultur 9\% dan semak belukar $4 \%$ dari total luas lahan pada kondisi aktual diubah menjadi hutan, adapun luas lahan kopi naungan sederhana dan agroforestri berbasis kopi tetap tidak berubah, sehingga luas hutan pada skenario 3 menjadi $23 \%$.

\section{d. Skenario 4}

Skenario ini dilakukan untuk mengacu pada Undang-Undang Nomor 26 Tahun 2007 tentang Penataan Ruang, yaitu ruang terbuka hijau minimal $30 \%$ dari total luasan. Luas lahan kopi monokultur 9\%, semak belukar 4\% dan agroforestri berbasis kopi $7 \%$ dari total luas lahan pada kondisi aktual diubah menjadi hutan, sedangkan agroforestri berbasis kopi menjadi $41 \%$ sehingga luas lahan hutan pada skenario 4 menjadi $30 \%$.

\section{e. Skenario 5}

Skenario ini hutan merupakan daerah yang tidak dapat diganggu dan sumber pendapatan masyarakat hanya bersumber pada lahan hortikultur dan persawahan.. Luas lahan kopi monokultur $9 \%$, semak belukar 4\%, kopi naungan sederhana 13\% dan agroforestri berbasis kopi $48 \%$ dari total luas lahan pada kondisi aktual diubah menjadi hutan sehingga luas lahan hutan pada skenario 5 menjadi $84 \%$.

\section{Penghitungan Debit Air}

Debit sungai merupakan komponen yang diperlukan untuk yaitu menjalankan turbin sehingga PLTA dapat memproduksi listrik yang dapat dijual dan menghasilkan pendapatan. Besarnya debit air pada setiap skenario komposisi penggunaan lahan dihitung dengan menggunakan model Aliran Sungai Generik (GenRiver). Model ini dikembangkan oleh World Agroforestry Centre berdasarkan proses hidrologi (process based model). Simulasi model GenRiver menggunakan Stella sebagai software yang dihubungkan dengan file microsoft excel. Input utama dari model ini adalah curah hujan, tingkat penutupan lahan dan sifat fisik tanah dengan keluaran utama berupa aliran sungai skala Daerah Aliran Sungai (DAS) (Gambar 3).

Komponen utama pada model GenRiver dan proses-proses yang terlibat di dalamnya adalah sebagai berikut:

\section{a. Curah hujan harian}

Curah hujan untuk skala sub-DAS diambil dari data empiris atau menggunakan data bangkitan dari pembangkit data acak (random generator) yang mempertimbangkan pola temporer atau model yang mempertimbangkan korelasi ruang (spatial correlation) dari hujan pada waktu tertentu.

\section{b. Intensitas hujan dan waktu untuk infiltrasi}

Intensitas hujan dihitung dari rata-rata data empiris intensitas hujan ( $\mathrm{mm} / \mathrm{jam})$ dengan mempertimbangkan koefisien variasi dari kumpulan data tersebut. Lamanya hujan menentukan waktu yang tersedia untuk proses infiltrasi, parameter ini dapat dimodifikasi dengan mempertimbangkan intersepsi oleh kanopi dan lamanya penetesan air dari kanopi (dripping phase) dengan penetapan awal. (default) 30 menit.

\section{c. Intersepsi}

Kapasitas penyimpanan air terintersepsi merupakan fungsi linier dari luas area daun dan ranting dari berbagai tipe penutupan lahan. 
Evaporasi dari air yang terintersepsi (interseption-evaporation) mempunyai prioritas sesuai dengan kebutuhan transpirasi tanaman.

\section{d. Infiltrasi dan aliran permukaan}

Proses infiltrasi dihitung berdasarkan nilai minimum dari:

a) Kapasitas infiltrasi harian dan waktu yang tersedia untuk infiltrasi (ditentukan oleh intensitas hujan dan kapasitas penyimpanan lapisan permukaan tanah).

b) Jumlah air yang dapat disimpan oleh tanah pada kondisi jenuh dan jumlah air yang dapat memasuki zona air tanah pada rentang waktu satu hari. Jika kondisi pertama yang terjadi maka Model akan menghasilkan aliran permukaan yang dibatasi oleh infiltrasi (infiltrasi limited runoff), sedangkan pada kondisi kedua aliran permukaan yang terjadi merupakan aliran jenuh permukaan (saturation overland flow).

\section{e. Evapotranspirasi}

Total evapotranspirasi yang digunakan dalam model ini mengikuti evapotranspirasi potensial Penman-Monteith dengan faktor koreksi yang dipengaruhi oleh:

a) Air yang terintersepsi oleh kanopi

b) Kondisi tutupan lahan yang terkait dengan sensitifitas setiap jenis penutupan lahan terhadap kekeringan

c) Faktor pembobot pada evapotranspirasi potensial harian yang mengikuti fenologi dan pola tanam

d) Relatif potensial evapotranspirasi (bulanan) untuk setiap tipe penutupan lahan

\section{f. Redistribusi air tanah}

Selama kejadian hujan tanah dapat mencapai kondisi jenuh air, namun sehari setelah hujan kondisi akan kembali pada kapasitas lapang (kondisi air tanah setelah 24 jam dari kejadian hujan lebat). Perbedaan antara kondisi jenuh dan kapasitas lapang dipengaruhi oleh:

a) transpirasi

b) adanya aliran air ke zona bawah

c) adanya aliran air ke sungai sebagai aliran cepat air tanah (soil quick flow) apabila air yang ada melebihi kapasitas lapang

\section{g. Pelepasan air Tanah menuju ke sungai (melalui aliran bawah tanah)}

\section{h. Jarak (routing distance)}

Jarak titik pengamatan atau outlet DAS ditentukan dari titik pusat masing-masing subDAS. Waktu tempuh (routing time) dari masingmasing sub-DAS dapat diturunkan dari data jarak dan asumsi rata-rata kecepatan aliran air.

\section{HASIL DAN PEMBAHASAN}

Perubahan penggunaan lahan telah menyebabkan perubahan jumlah debit sungai yang dihasilkan. Pada skenario penggunaan lahan hutan sebanyak $84 \%$ dari total luas lahan memberikan jumlah debit sungai yang paling kecil dibandingkan skenario yang lain sedangkan jumlah debit sungai terbesar dihasilkan pada skenario lahan monokultur sebanyak $13 \%$, hutan $10 \%$ dan agroforestri berbasis kopi sebanyak 48 $\%$. Total pendapatan PLTA Way Besai terbanyak dihasilkan pada skenario penggunaan lahan monokultur sedangkan terendah pada pola penggunaan lahan hutan seluas $84 \%$. Tabel 2 menyajikan debit sungai, produksi listrik dan total pendapatan PLTA dari hasil simulasi pada berbagai skenario.

Tabel(Table) 2. Debit sungai, produksi listrik dan total pendapatan PLTA pada berbagai skenario penggunaan lahan di lokasi penelitian (River debit, electricity production and total hydropower income of landuse scenarios at research location)

\begin{tabular}{|l|c|c|c|}
\hline \multicolumn{1}{|c|}{ Skenario perubahan lahan } & Jumlah Debit (m3/th) & $\begin{array}{c}\text { Produksi listrik } \\
\text { (Mwatt/th) }\end{array}$ & $\begin{array}{c}\text { Pendapatan } \\
\text { (juta Rp/th) }\end{array}$ \\
\hline Aktual & $7.395,3$ & $282.299,1$ & $359.106,73$ \\
\hline Skenario 1 & $7.438,3$ & $283.881,0$ & $361.085,82$ \\
\hline Skenario 2 & $7.241,8$ & $276.671,6$ & $352.252,00$ \\
\hline Skenario 3 & $7.089,0$ & $270.455,6$ & $345.094,00$ \\
\hline Skenario 4 & $6.977,4$ & $265.747,1$ & $339.916,00$ \\
\hline Skenario 5 & $6.354,0$ & $241.300,3$ & $310.717,00$ \\
\hline & & & $18.498,47$ \\
\hline Standar deviasi $\left.{ }^{*}\right)$ & & & \\
\hline
\end{tabular}

Keterangan (Remarks):*) Standar deviasi dihitung dari total pendapatan untuk semua skenario (Standard deviation is calculated from the total revenue for all scenarios) 


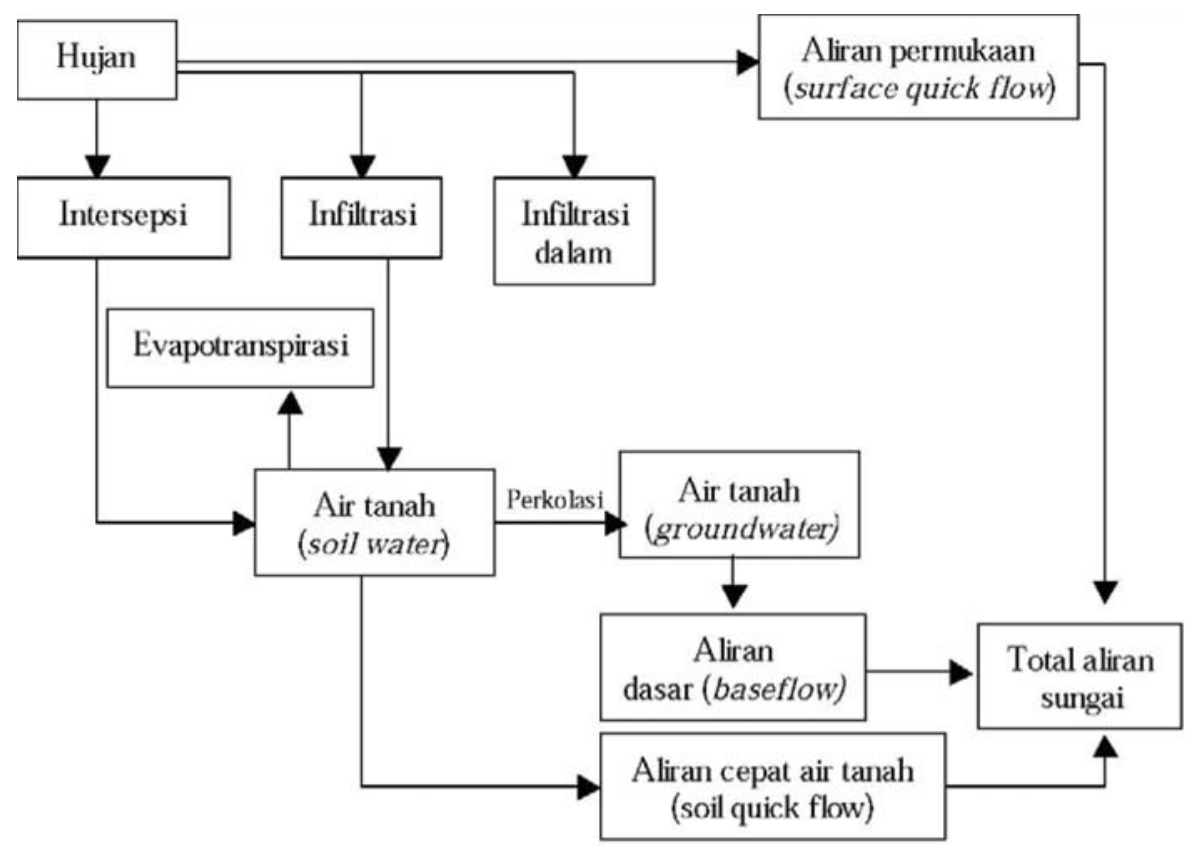

Gambar(Figure) 3. Diagram alur proses hidrologi pada GenRiver (Flowchart diagram of hidrology process at GenRiver) (Van Noordwijk, et.al. 2003).

Penurunan debit air yang digunakan untuk menjalankan turbin berakibat pada penurunan produksi listrik dan akhirnya pada nilai pendapatan PLTA. Meskipun pada skenario lainya, yaitu 2, 3 dan 4 juga mengalami penurunan debit air bila dibandingkan dengan skenario 1 , tetapi penurunannya tidak nyata berdasarkan standar deviasinya. Demikian pula dengan produksi listrik dan pendapatan PLTA.

Bila dibandingkan dengan kondisi aktual, skenario 1 terjadi kecenderungan peningkatan debit akibat perubahan dari belukar sebanyak 4\% menjadi kopi monokultur. Kopi monokultur relatif bersih dari tumbuhan bawah bila dibandingkan dengan belukar yang didominasi tumbuhan bawah. Dengan demikian pembukaan belukar memicu terjadinya aliran permukaan sehingga apabila terjadi hujan maka aliran permukaan akan meningkat dan meningktkan debit air sungai.

Jumlah debit air, produksi listrik dan pendapatan PLTA pada tiap-tiap skenario perubahan penggunaan lahan adalah:

\section{Skenario 1: Penggunaan lahan tanaman kopi monokultur}

MMerubah semak belukar seluas 2.168 ha (4\%) dari total lahan (aktual) di Kecamatan Sumberjaya menjadi kopi monokultur. Dengan demikian, pada skenario 1, luas kopi monokultur menjadi 7.046 ha (13\%), yaitu 4.878 ha $(9 \%)$ yang ada saat ini ditambah 2.168 ha (4\%) konversi dari semak belukar. Komposisi untuk luas penggunaan lahan lainnya tetap, yaitu hutan 5.420 ha (10\%), kopi naungan sederhana 7.046 ha (13\%), Agroforestri berbasis kopi 26.016 ha $(48 \%)$, hortikultura 1.626 ha $(3 \%)$, persawahan 5.420 ha $(10 \%)$ dan pemukiman 1.626 ha (3\%). Perubahan penggunaan lahan dengan mengubah semak belukar seluas 2.168 ha (4\%) menjadi kopi monokultur menghasilkan debit rata-rata sungai di Sub-DAS Way Besai sebesar 6.846,00 $\mathrm{m}^{3} /$ detik yang digunakan oleh PLTA untuk menggerakkan kedua turbinnya dan menghasilkan produksi listrik sebanyak 261.655,50 MW (mega watt). Jika menggunakan harga jual listrik sebesar $\mathrm{Rp} 1,38$,- per watt, maka pada skenario 1 diperoleh pendapatan PLTA Way Besai sebesar Rp 361.085.000.000,00.

\section{Skenario 2: Penggunaan Lahan berupa Agroforestri berbasis kopi}

Skenario 2 adalah mengubah penggunaan lahan dari kondisi aktual yaitu lahan kopi monokultur seluas 4.878 ha (9\%) dan semak belukar seluas 2.168 ha (4\%) menjadi Agroforestry berbasis kopi, sehingga total luas lahan agroforestri berbasis kopi bertambah dari seluas 26.016 ha (48\%) menjadi seluas 33.062 ha (61\%). Luas lahan untuk penggunaan lainnya tetap yaitu hutan seluas 5.420 ha $(10 \%)$, kopi naungan sederhana seluas 7.046 ha (13\%), horti- 
kultura seluas 1.626 ha (3\%), persawahan seluas 5.420 ha (10\%) dan pemukiman seluas 1.626 ha (3\%).

Hasil simulasi dengan penggunaan lahan agroforestry berbasis kopi seluas 33.062 ha (61\%), maka debit rata-rata sungai di Sub-DAS Way Besai sebesar $6.670,00 \mathrm{~m}^{3} /$ detik dan digunakan oleh PLTA untuk menggerakkan kedua turbin sehingga menghasilkan produksi listrik sebanyak 255.255,20 MW (mega watt). Dengan menggunakan harga jual listrik sebesar Rp 1,38 per watt, maka dengan skenario 2 diperoleh pendapatan PLTA Way Besai sebesar Rp 352.252.000.000,00.

\section{Skenario 3: Penggunaan lahan hutan seluas 12.466 ha $(23 \%)$}

Skenario 3 adalah mengubah penggunaan lahan dari kondisi aktual dari kopi monokultur seluas 4.878 ha (9\%) dan semak belukar seluas 2.168 ha (4\%) menjadi hutan, sehingga total luas lahan hutan bertambah dari seluas 5.420 ha (10\%) menjadi luas 12.466 ha (23\%) seperti pada Tabel 9. Penggunaan lahan lainnya tetap yaitu kopi naungan sederhana seluas 7.046 ha (13\%), agroforestry berbasis kopi seluas 7.046 ha (48\%), hortikultura seluas 1.626 ha (3\%), persawahan seluas 5.420 ha $(10 \%)$ dan pemukiman seluas 1.626 ha (3\%).

Beradasarkan skenario 3 dengan penggunaan lahan hutan seluas 12.446 ha (23\%) menghasilkan debit rata-rata sungai di Sub-DAS Way Besai sebesar $6.546,40 \mathrm{~m}^{3} /$ detik yang digunakan PLTA untuk menggerakkan kedua turbinnya dan menghasilkan produksi listrik sebanyak 250.068,20 MW (mega watt). Dengan menggunakan harga jual listrik sebesar Rp 1,38 per watt, maka pada skenario 3 diperoleh pendapatan PLTA Way Besai sebesar Rp 345.094.000.000,00.

\section{Skenario 4: Penggunaan lahan hutan Seluas $30 \%$}

Skenario 4 adalah mengubah penggunaan lahan dari kondisi aktual yaitu kopi monokultur seluas 4.878 ha (9\%) dan semak belukar seluas 2.168 ha (4\%) menjadi hutan, dan mengurangi luas penggunaan agroforestri berbasis kopi seluas 4.878 ha (7\%), yaitu dari seluas 26.016 ha (48\%) menjadi seluas 21.138 ha (41\%), sehingga total luas lahan hutan bertambah dari 5.420 ha (10\%) menjadi seluas 16.260 ha (30\%). Penggunaan lahan lainnya yaitu kopi naungan sederhana seluas 7.046 ha (13\%), hortikultura seluas 1.626 ha (3\%) persen, persawahan seluas 5.420 ha (10\%) dan pemukiman seluas 1.626 ha (3\%).
Dari skenario 4 dengan penggunaan lahan hutan seluas 16.260 ha $(30 \%)$ menghasilkan debit rata-rata sungai di Sub-DAS Way Besai sebesar $6.466,70 \mathrm{~m}^{3} /$ detik yang digunakan PLTA untuk menggerakkan kedua turbinnya dan menghasilkan produksi listrik sebanyak 246.316,30 MW (mega watt). Dengan menggunakan harga jual listrik sebesar $\mathrm{Rp}$ 1,38 per watt, maka pada skenario 4 diperoleh pendapatan PLTA Way Besai sebesar Rp 339.916.000.000,00.

\section{Skenario 5: Penggunaan lahan semua hutan seluas $84 \%$}

Skenario 5 adalah mengubah penggunaan lahan dari kondisi aktual berupa kopi monokultur seluas 4.878 ha $(9 \%)$, semak belukar seluas 2.168 ha (4\%), kopi naungan sederhana 7.046 ha $(13 \%)$, agroforestri berbasis kopi 26.016 ha (48\%) menjadi hutan, sehingga luas hutan menjadi 45.528 ha (84\%) seperti pada Tabel 9. Sedangkan penggunaan lahan untuk hortikultura seluas 1.626 ha (3\%), persawahan seluas 5.420 ha $(10 \%)$ dan pemukiman seluas 1.626 ha ( $3 \%)$ tetap tidak berubah.

Skenario 5 dengan penggunaan lahan hutan seluas 45.528 ha (84\%) menghasilkan debit rata-rata sungai di Sub-DAS Way Besai sebesar $5.928,40 \mathrm{~m}^{3} /$ detik yang dipakai PLTA untuk menggerakkan kedua turbinnya dan menghasilkan produksi listrik sebanyak 225.156,90 MW (mega watt). Dengan menggunakan harga air sebagai faktor produksi sebesar Rp 1,38 per watt, maka pada skenario ini didapatkan pendapatan PLTA Way Besai sebesar Rp 310.717.000.000.

Apabila dibandingkan antara kondisi aktual dengan skenario 1, 2, 3, 4 dan 5 maka total pendapatan PLTA Way Besai di Kecamatan Sumberjaya berbeda nyata antara aktual dengan skenario 5, Skenario 1 dengan 5 dan Skenario 2 dengan 5 (Tabel. 3). Hal ini menunjukkan bahwa secara statistik pendapatan PLTA Way Besai pada penggunaan lahan aktual, skenario 1 dan skenario 2 lebih besar dibandingkan pada skenario 5 .

Penelitian ini menunjukkan bahwa pada Skenario 1 dengan $13 \%$ dari total luas lahan (semak belukar diubah menjadi kopi monokultur) total pendapatan PLTA Way Besai di Kecamatan Sumberjaya, Lampung adalah yang paling tinggi sebesar Rp 361.085,82 juta per tahun. Apabila dibandingkan antara kondisi aktual dengan skenario 1 sampai dengan 5 maka total pendapatan PLTA Way Besai berbeda nyata antara aktual dengan skenario 5, skenario 1 
Tabel(Table) 3. Matrik perbedaan total pendapatan PLTA pada tiap-tiap skenario perubahan penggunaan lahan (matric of difference hydropower income on landuse change scenarios)

\begin{tabular}{|l|r|r|r|r|r|c|}
\hline \multirow{2}{*}{$\begin{array}{c}\text { Skenario } \\
\text { perubahan } \\
\text { lahan }\end{array}$} & \multirow{2}{*}{ Aktual } & \multicolumn{5}{|c|}{ Skenario } \\
\cline { 3 - 7 } & & 1 & 2 & \multicolumn{1}{c|}{3} & \multicolumn{1}{c|}{4} & \multicolumn{1}{c|}{5} \\
\hline Aktual & 0 & $1.979,09$ & $6.854,73$ & $14.012,73$ & $19.190,73$ & $48.389,73^{\text {a) }}$ \\
\hline Skenario 1 & & 0 & $8.833,82$ & $13.991,82$ & $21.169,82$ & $50.368,82^{\text {b) }}$ \\
\hline Skenario 2 & & & 0 & $7.158,00$ & $12,336,00$ & $41.535,00^{\mathrm{c}}{ }^{\mathrm{n}}$ \\
\hline Skenario 3 & & & & 0 & $5.178,00$ & $34.377,00$ \\
\hline Skenario 4 & & & & & 0 & $29.199,00$ \\
\hline Skenario 5 & & & & & & 0 \\
\hline
\end{tabular}

Keterangan (Remarks): Nilai yang a),b) dan c) menunjukkan perbedaan yang nyata berdasarkan standar deviasi (Value a), b) and c) indicate significant differences based on the standard deviation)

dengan skenario 5 dan skenario 2 dengan skenario 5. Hal ini menunjukkan bahwa pendapatan pada aktual, skenario 1 dan skenario 2 dibandingkan dengan skenario 5 berbeda jumlahnya secara statistik. Sedangkan antara aktual dengan skenario 1 , skenario 2 , skenario 3 dan dengan skenario 4 tidak berbeda nyata, dengan demikian tingkat pendapatan PLTA Way Besai tidak menunjukkan berbeda jumlahnya secara statistik (Tabel 3).

Skenario 2 agroforestri berbasis kopi memberikan total pendapatan PLTA Way Besai sebesar Rp 339.095.140.000 per tahun. Pada tingkat sistem penggunaan lahan, agroforestri berbasis kopi lebih menguntungkan secara ekologis dibandingkan dengan kopi monokultur. Manfaat ekologi tersebut, antara lain berperan dalam mengatur fungsi tata air, pengatur iklim lokal dan pelestari keanekaragaman hayati. Agroforestri berbasis kopi memiliki berbagai jenis serasah dengan tingkat pelapukan yang berbeda, sehingga berperan menghambat limpasan permukaan dan erosi (Hairiah et al., 2004; Dariah et al., 2004). Sistem monokultur yang diadopsi petani dalam jangka panjang akan mengakibatkan menurunnya fungsi tata air (Suyamto et al., 2004).

Perubahan penggunaan lahan akan mempengaruhi besarnya debit sungai Way Besai. Pada skenario 5 dengan 84\% tutupan lahan berupa hutan, rata-rata tahunan debit sungai cenderung mengalami penurunan. Hal ini disebabkan karena pada lahan hutan dengan struktur dan komposisi yang beragam serta seresah yang terdapat di lantai hutan akan mempengaruhi siklus hidrologi. Vegetasi berupa pepohonan di hutan berperan dalam pemindahan (transfer) air hujan ke tanah melalui proses penahanan sementara air hujan oleh tajuk pohon, aliran batang dan air lolos serta sebagai media pemindahan air dari dalam tanah ke vegetasi dan ke atmosfer melalui evapotranspirasi akan mengalami perubahan.

Butir-butir air hujan yang jatuh ditahan oleh tajuk pohon sebagian dialirkan perlahanlahan melalui batang yang disebut sebagai aliran batang (stem flow), sebagian jatuh langsung dari tajuk atau melalui penetesan dari daun dan cabang-cabang pohon yang disebut sebagai air lolos (through fall) dan sebagian lagi tertahan sementara oleh tajuk kemudian diuapkan kembali ke udara yang disebut sebagai air intersepsi (Pudjiharta dan Sallata, 1985). Bruijnzeel (1990), menyatakan bahwa intersepsi di hutan hujan tropis berkisar antara 10-35\% dari curah hujan total.

Pola penggunaan lahan tanaman kopi monokultur maupun agroforestri berbasis kopi dilihat dari sisi jumlah maupun komposisi vegetasi lebih sedikit dibandingkan dengan vegetasi yang ada di hutan, dengan demikian tingkat evapotranspirasi di lahan berhutan lebih tinggi dibandingkan di lahan tanaman kopi karena tajuk tanaman yang menahan air hujan dan akan menguapkan kembali ke atmosfir lebih rapat serta air yang sampai ke lantai hutan lebih sedikit sehingga jumlah debit rata-rata per tahun semakin berkurang dengan semakin luasnya lahan yang berhutan. Hal ini terlihat dengan semakin bertambahnya tutupan lahan berupa hutan maka jumlah debit rata-rata per tahun semakin menurun.

Sementara jika membandingkan penelitian tentang intersepsi pada hutan tidak terganggu dan hutan tebangan yang dilakukan oleh Asdak et al. (1998) di Kalimantan Tengah ternyata menunjukkan bahwa besarnya intersepsi meningkat dengan rapatnya tajuk vegetasi, dalam hal ini $0,7 \%$ di lokasi tanpa tajuk, serta meningkat menjadi $4,5 \%$ dan $15 \%$ masing-masing di lokasi dengan penutupan tajuk sedang dan penutupan tajuk rapat. Dengan kata lain semakin kecil 


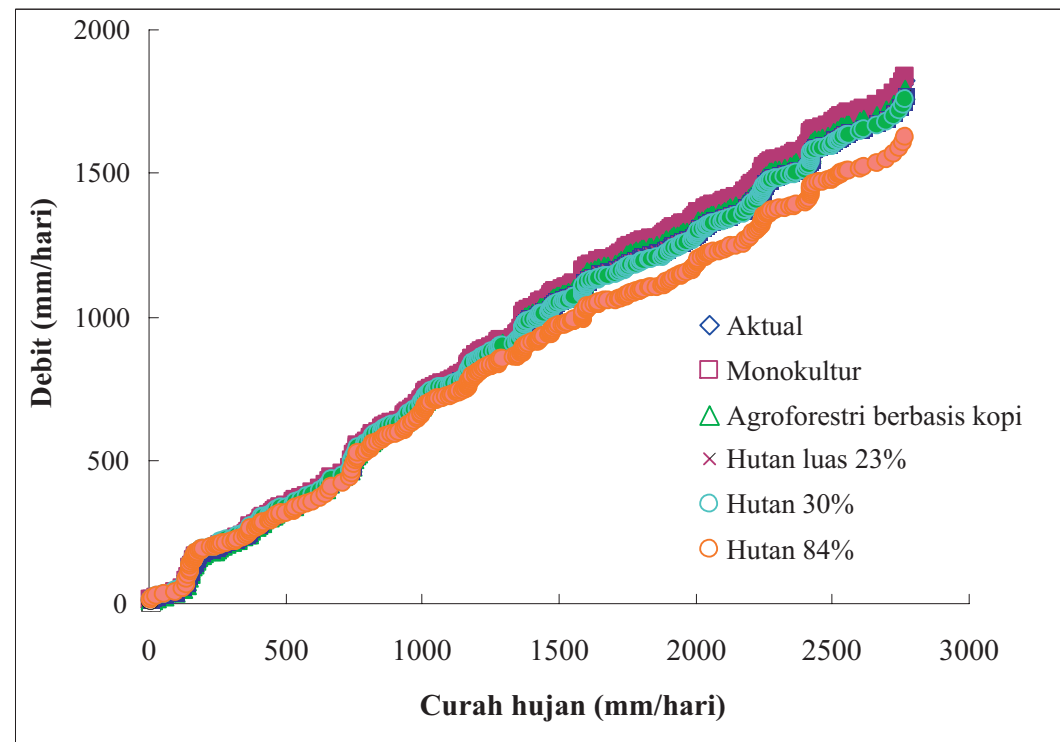

Gambar(Figure) 4. Besaran debit sungai yang dihasilkan pada berbagai skenario pola penggunaan lahan (Magnitude of river discharge is produced on various scenarios of land use patterns)

penutupan tajuk vegetasi sebagai akibat perubahan penggunaan lahan, semakin besar air lolos yang akan sampai ke permukaan tanah dan dengan demikian menurunkan jumlah air terintersepsi yang pada gilirannya akan meningkatkan debit aliran.

Hasil simulasi dari lima skenario terlihat bahwa tingkat debit terendah dihasilkan pada skenario 5 (hutan 84\%) sedangkan debit tertinggi dihasilkan pada skenario 1 (monokultur). Gambar 1 menampilkan besarnya debit pada beberapa skenario pola penggunaan lahan.

Dengan demikian skenario penggunaan lahan agroforestri berbasis kopi memberikan total pendapatan yang lestari bagi PLTA Way Besai dengan mengurangi tambahan biaya yang harus dikeluarkan dengan adanya pengurangan sedimentasi di waduk bendungan sedangkan total pendapatan tidak mengalami perubahan yang berbeda nyata. Tampubolon (2007) penelitian yang dilakukan di DAS Citarum, Jawa Barat menemukan bahwa penurunan pendapatan (kerugian) PLTA Saguling sebesar Rp 138,617 miliar setiap tahun yang disebabkan oleh peningkatan besarnya kehilangan kesempatan produksi, baik sebagai akibat penurunan volume air masuk lokal, peningkatan sedimentasi di waduk maupun peningkatan frekuensi pemeliharaan alat utama produksi (turbin dan cooler). Sedangkan Vieth et al. (2001) kehilangan produksi listrik yang diakibatkan perubahan penggunaan lahan di daerah hulu DAS Mahaweli di Sri Lanka pada tahun 1993 sebesar \$288.720.

\section{KESIMPULAN}

1. Perubahan penggunaan lahan telah menyebabkan perubahan debit sungai yang dihasilkan. Pola penggunaan dengan skenario 5 (lahan hutan seluas $84 \%$ ) mengasilkan debit sungai yang paling rendah sedangkan debit sungai tertinggi dihasilkan pada skenario 1 (monokultur).

2. Pola penggunaan lahan yang dapat memberikan kelestarian total pendapatan PLTA Way Besai adalah skenario 2 (agroforestry berbasis kopi) dapat dicapai dengan memanfaatkan semak belukar seluas $4 \%$ dan mengubah kopi monokultur seluas $9 \%$ yang saat ini masih ada menjadi agroforestry berbasis kopi.

3. Menghutankan seluruh areal yang saat ini ditanami kopi (agroforestri berbasis kopi, naungan sederhana, kopi monokultur) dan semak belukar akan menurunkan total pendapatan PLTA Way Besai hingga $13,5 \%$.

\section{DAFTAR PUSTAKA}

Asdak, C., P.G. Jarvis, P. Van Gardingen. dan A. Fraser. 1998. Rainfall Interception Loss in Unlogged and Logged Forest Areas of Central Kalimantan, Indonesia. J.Hydrol. (206):234-244. 
Asdak, C. 2002. Hidrologi dan Pengelolaan Daerah Aliran Sungai. Gajah Mada University Press. Yogjakarta.

Bruijnzeel, L.A. 2004. Hydrological Functions of Tropical Forests: Not Seeing the Soil for the Trees? Agriculture, Ecosystems and Environment.

Dariah, A, F. Agus., S. Arsyad, Sudarsono, dan Maswar. 2004. Erosi dan Aliran Permukaan pada Lahan Pertanian Berbasis Tanaman Kopi di Sumberjaya, Lampung Barat. Agrivita 26(1): 52-60

Hairiah, K., Widianto, D. Suprayogo, R.H Widodo, P. Purnomosidhi., S. Rahayu, dan M. van Noordwijk. 2004. Ketebalan Seresah sebagai Indikator Daerah Aliran Sungai (DAS) Sehat. World Agroforestry Centre (Icraf). Bogor.

Millennium Ecosystem Assessment. 2005. Ecosystems and Human Well-being: Synthesis.

O'Connor,T., S. Rahayu, dan M. van Noordwijk. 2005. Burung pada Agroforestry Kopi di Lampung: World Agroforestry Centre (Icraf), Bogor. Bogor

Pudjiharta, A. dan M.K. Sallata. 1985. Aliran Batang, Air Lolos dan Intersepsi Curah Hujan pada Tegakan Pinus merkusii di Daerah Hutan Tropik Cikole, Lembang, Jawa Barat. Pusat Penelitian dan Pengembangan Hutan, Bogor. Buletin Penelitian Hutan (471):49-62

Suyamto, D.A., M. van Noordwijk, dan B. Lusiana. 2004. Respon Petani Kopi terhadap Gejolak Pasar dan Konsekuensinya terhadap Fungsi Tata Air: Suatu Pendekatan Pemodelan. Agrivita 26(1): $108-130$

Tampubolon, R. 2007. Pengaruh Kualitas Lingkungan terhadap Biaya Eksternalitas Pengguna Air Citarum. Program Pasca Sarjana IPB. Bogor.

Tietenberg, T. 1992. Environmental and Natural Economics. $3^{\text {rd }}$ edition. Haper Collin Publisher Inc. New York

Verbist, B., A.N. Ekadinata, and S. Budidarsono. 2005. Factors Driving Land Use Change: Effects on Watershed Functions in a Coffee Agroforestry System in Lampung, Sumatra. Agricultural Systems 85: 254270

Van Noordwijk, M., A. Farida, A.B. Verbist, dan T. Tomich. 2003. Agroforestry and Watersheed Fuctions of Tropical Land Use Mosaics. Proceeding $2^{\text {nd }}$ Asia Pasific Training Workshop on Ecohydrology. Cibinong, July 21-26, 2003. Bogor.

Van Noordwijk, M., S. Rahayu, K. Hairiah,Y.C Wulan, A. Farida, dan B. Verbist. 2002. Carbon Stock Assessment for a Forestto-Coffee Conversion Landscape in Sumberjaya (Lampung, Indonesia): from allometric equation to Land Use Change Analysis. Sciene in China 45: 75-86

Vieth, G. R., H. Gunatilake, and L.J. Cox. 2001. Economic of Soil Conservation: The Upper Mahaweli Watershed of Sri Lanka. Journal of Agricultural Economic 52: 139152. 